\title{
Cortical Blindness: Etiology, Diagnosis, and Prognosis
}

\author{
Michael S. Aldrich, MD,* Anthony G. Alessi, MD, ${ }^{*}$ Roy W. Beck, MD, $\ddagger$ and Sid Gilman, MD $\dagger$
}

\begin{abstract}
We examined 15 patients with cortical blindness, reviewed the records of 10 others, and compared these 25 patients to those in previous studies of cortical blindness. Although cerebrovascular disease was the most common cause in our series, surgery, particularly cardiac surgery, and cerebral angiography were also major causes. Only 3 patients denied their blindness, although 4 others were unaware of their visual loss. Electroencephalograms (EEGs) were performed during the period of blindness in 20 patients and all recordings were abnormal, with absent alpha rhythm. Visual evoked potentials recorded during blindness were abnormal in 15 of 19 patients, but did not correlate with the severity of visual loss or with outcome. Bioccipital lucencies were found in computed tomographic (CT) scans of 14 patients; none of the 14 regained good vision. Recovery of vision was poor in all 8 patients who had a spontaneous stroke, but fair or good in 11 of the other 17 patients. Prognosis was best in patients under the age of 40 years, in those without a history of hypertension or diabetes mellitus, and in those without associated cognitive, language, or memory impairments. We conclude that (1) the prognosis in cortical blindness is poor when caused by stroke; (2) EEGs are more useful than visual evoked potentials for diagnosis; and (3) bioccipital abnormalities shown on CT scan are associated with a poor prognosis.
\end{abstract}

Aldrich MS, Alessi AG, Beck RW, Gilman S: Cortical blindness: etiology, diagnosis, and prognosis. Ann Neurol 21:149-158, 1987

Cortical or cerebral blindness (CB) refers to loss of vision produced by lesions affecting geniculocalcarine visual pathways. Complete $\mathrm{CB}$ is much less common than incomplete blindness.

Six series of patients with $\mathrm{CB}$ have been reported $[5,9,19,32,35,44]$. Reese [35] reported that the prognosis was better for $\mathrm{CB}$ occurring after ventriculography than for $\mathrm{CB}$ caused by vascular disease. Symonds and Mackenzie [44] noted that in $\mathrm{CB}$ due to vascular causes, loss of vision was usually sudden; blindness was permanent in a quarter of the patients; and denial, hallucinations, visual agnosia, and spatial disorientation were inconstant features. Bergman [5] noted the absence of alpha activity in the electroencephalogram (EEG) and its reappearance with recovery of vision. Nepple and colleagues [32] described 15 patients with bilateral homonymous hemianopia; the most common causes were vascular disease, uncal herniation, and migraine. Bogousslavsky and associates [9] prospectively followed 58 patients with unilateral homonymous hemianopia and found that 13 developed cortical blindness.

In this study we report the clinical characteristics and laboratory results in 25 patients with cortical blindness in an attempt to determine: (1) whether there has been a change in the distribution of causes of $\mathrm{CB}$ in the last 10 years; (2) the frequencies of specific features of $\mathrm{CB}$ and their relation to etiology, including denial and unawareness of blindness, visual distortions and hallucinations, and electrophysiological abnormalities; (3) whether these features are helpful in the diagnosis of $\mathrm{CB}$; and (4) whether specific clinical, radiological, or electrophysiological findings can be used to predict prognosis.

\section{Methods}

We reviewed the charts of all adult inpatients with a discharge diagnosis of $\mathrm{CB}$, central visual disturbance, or unclassified visual disturbance who were seen at the University of Michigan Hospitals berween 1974 and 1984. Between June 1982 and June 1984, patients with CB were examined by one or more of the authors, as were previously diagnosed patients who returned for follow-up. Patients were considered to have had cortical blindness if severe bilateral homonymous visual deficits had developed that lasted longer than 24 hours, and if there were reactive pupils and no evidence of an ocular or psychogenic cause of blindness. From a total of 351 chart reviews and patient examinations, we identified 25 patients with CB. An additional 11 patients had cortical blindness for less than 24 hours due to transient ischemic attacks ( $(n=5)$, migraine $(n=3)$, angiography (
From the Departments of *Neurology, †Neurosurgery, and $\ddagger$ Ophthalmology, University of Michigan Medical Center, Ann Arbor, MI.

Received Mar 25, 1986, and in revised form June 17. Accepted for publication June 18, 1986.
Address reprint requests to Dr Aldrich, Department of Neurology, 1920/0316 Taubman Center, University of Michigan Hospitals, Ann Arbor, MI 48109-0316. 
$=2)$, or seizures $(n=1)$. The most common diagnoses in the remaining 315 patients were homonymous hemianopia, amaurosis fugax, and optic neuritis. All patients had been examined by a neurologist or an ophthalmologist; 15 of the patients had been examined by one or more of the authors.

For each of the 25 patients, we reviewed the clinical course, findings from neurological and ophthalmological examinations, and the results of computed tomographic (CT) brain scans, EEGs, flash visual evoked potentials (FVEPs) and pattern reversal visual evoked potentials (PRVEPs). We evaluated cognitive, language, and memory functions with bedside tests of the ability to: (1) recall three objects at 1 and 3 minutes; (2) recall names of presidents of the United States; (3) repeat strings of digits forwards and backwards; (4) subtract sevens serially from 100 ; (5) perform simple arithmetic; (6) discriminate right and left; (7) follow one- and twostep commands; (8) repeat and write short sentences; and (9) name objects. For the purpose of this study, we defined preexisting visual field deficits as those present for at least 1 month prior to the onset of blindness. We rated the outcome as good (when vision returned to the previous level), fair (when visual acuity was 20/100 or better in both eyes and there was a consistent ability to count fingers in at least one hemifield), or poor (when visual acuity was less than 20/100 in both eyes and there was no consistent ability to count fingers in more than one quadrant).

CT brain scans were obtained in 19 patients. In all cases, the slice image width was $10 \mathrm{~mm}$, and the slice angle was 15 degrees from the canthomeatal line (except for Patient 17 in whom the slice angle was 0 degrees). For each $\mathrm{CT}$ slice image, the region of abnormality was plotted on a standardized slice template $[21,30]$.

EEGs were assessed for the presence of: (1) a visually detectable alpha rhythm, defined as a posterior dominant 8 to $13-\mathrm{Hz}$ rhythm present during wakefulness and responsive to eye opening; (2) photic driving, defined as any visually detectable posterior rhythm, time-locked to stimulation delivered by conventional EEG photic stimulators; and (3) focal or diffuse slow-wave abnormalities or epileptiform abnormalities. Visual evoked potentials (VEPs) were assessed for the presence of abnormalities of amplitude or latency. Optokinetic responses were defined as any reproducible eye movement that could be elicited with a striped tape or striped drum. The Wilcoxon rank order method was used to assess statistical significance.

\section{Results}

Clinical features of the 25 patients are presented in Table 1. The most common causes of CB were spontaneous ischemic stroke (32\%), cardiac surgery (20\%), and cerebral angiography (12\%) (Table 2). Of the 5 patients with CB following cardiac surgery, 2 suffered cardiac arrests (Patients 12 and 13) and 1 had CT evidence of multiple cerebral emboli (Patient 10). Three patients were blind after noncardiac surgery and 1 was comatose after surgery and awoke with blindness. For cases unrelated to surgical procedures, the onset of visual loss varied: 10 patients became blind suddenly, although 2 of them had experienced prior amaurosis.
Three developed a partial field loss, followed several days later by loss of the remaining vision, and 3 described a period of gradual visual deterioration over several minutes or hours. Three patients had permanent complete blindness and several others described a period of complete visual loss but had some perception of light or motion at the time of examination days or weeks later. Two patients complained of a more severe visual loss than was indicated by objective testing. Frank denial occurred in only 3 patients and was variably accompanied by complaints of poor lighting and by confabulated descriptions of objects and faces. Four other patients, all of whom had experienced visual disturbance after cardiac surgery, appeared inattentive to their visual loss or were not fully aware of it. Five patients complained of visual difficulty apparently within minutes of the onset. These included 2 patients whose blindness developed during radiological procedures.

Two patients had partial seizures with visual hallucinations during the onset of blindness, documented by ictal EEG recordings. One had a prolonged hallucination of flashing red lights in the left hemifield [3], and the other had repeated images of four friends moving from left to right across his visual field. Four other patients experienced illusions or hallucinations, 1 during the onset of blindness and the other 3 during recovery.

\section{Diagnostic Studies}

CT brain scans were obtained in 19 patients (Figs 1 through 3). Unilateral abnormalities were present in 2 , and bilateral abnormalities were present in 14. Two patients had normal CT scans done on the day of onset of blindness, but follow-up CT scans were not obtained. In 1 patient (No 16), who regained full vision after several weeks, a CT scan done 4 months later was normal.

The variability of the CT appearance in the 14 patients with bilateral abnormalities suggested that not all cases were due to bilateral posterior cerebral artery thrombosis. Cerebellar involvement in Patients 1 and 2 suggested basilar artery occlusion, while relatively small areas of infarct suggested posterior cerebral branch artery occlusions or watershed infarctions in Patients 19 and 20. In all 14 patients, the occipital pole was involved bilaterally. Involvement of the parietal lobe was usually associated with additional cognitive deficits but not with worsened vision.

EEGs were performed in 20 patients during the period of visual loss (Table 3 ). All showed abnormalities consisting of slowing of the posterior dominant rhythm and focal slow waves. A well-developed alpha rhythm was absent in all 20. One patient (No 8) had a prominent $10-\mathrm{Hz}$ mu rhythm over the central regions, which did not react to eye opening, and 4 others had inter- 
Table 1. Clinical Features of 25 Patients with Cortical Blindness

\begin{tabular}{|c|c|c|c|c|}
\hline $\begin{array}{l}\text { Patient No. } \\
\text { (Age/Sex) }\end{array}$ & Cause & $\begin{array}{l}\text { Prior VF } \\
\text { Deficit }\end{array}$ & Associated Neurological Deficit & Outcome \\
\hline $1(70 / \mathrm{M})$ & Stroke & $\cdots$ & $\begin{array}{l}\text { Amnesia, right facial weakness, } \\
\text { color agnosia, finger agnosia, } \\
\text { ocular apraxia, astereognosis }\end{array}$ & $\begin{array}{l}\text { No improvement; died } 6 \text { months } \\
\text { later }\end{array}$ \\
\hline $2(53 / \mathrm{M})$ & Stroke & $\cdots$ & $\begin{array}{l}\text { Amnesia, left facial weakness, } \\
\text { simultagnosia, agraphesthesia, } \\
\text { spatial disorientation }\end{array}$ & $\begin{array}{l}\text { No improvement; died } 3 \text { weeks } \\
\text { later }\end{array}$ \\
\hline $3(62 / \mathrm{F})$ & Stroke & $\ldots$ & Coma; later disorientation & No improvement 6 months later \\
\hline $4(46 / M)$ & Stroke & $\ldots$ & $\begin{array}{l}\text { Dysarthria, quadriparesis, } \\
\text { amnesia, spatial disorientation, } \\
\text { acalculia, left sensory neglect }\end{array}$ & No improvement 5 months later \\
\hline $5(69 / \mathrm{M})$ & Stroke & $\ldots$ & None & No improvement 1 year later \\
\hline $6(65 / M)$ & Stroke & RHH & $\begin{array}{l}\text { Amnesia, apraxia, aphasia, } \\
\text { acalculia, spastic dysarthria, } \\
\text { astereognosis, left hemiparesis, } \\
\text { pseudobulbar effect, spatial } \\
\text { disorientation, ocular apraxia }\end{array}$ & $\begin{array}{l}\text { Regained color vision; died } 5 \\
\text { weeks later }\end{array}$ \\
\hline $7(70 / \mathrm{M})$ & Stroke & $\mathrm{LHH}$ & $\begin{array}{l}\text { Amnesia, acalculia, agraphia, spa- } \\
\text { tial disorientation, left hemi- } \\
\text { paresis, right sensory neglect }\end{array}$ & No improvement 6 weeks later \\
\hline $8(75 / F)$ & Stroke & $\ldots$ & Acalculia & $\begin{array}{l}\text { Regained only macular vision } 8 \\
\text { months later }\end{array}$ \\
\hline $9(58 / F)$ & $\begin{array}{l}\text { Coronary } \\
\text { artery bypass } \\
\text { and left carotid } \\
\text { endarterectomy }\end{array}$ & $\ldots$ & $\begin{array}{l}\text { Coma; later aphasia, acalculia, } \\
\text { astereognosis, agraphesthesia, } \\
\text { right hemiparesis }\end{array}$ & No improvement 1 year later \\
\hline $10(66 / \mathrm{M})$ & $\begin{array}{l}\text { Coronary } \\
\text { artery bypass }\end{array}$ & $\cdots$ & Disorientation & $\begin{array}{l}\text { Improved to } 20 / 100 \text { OU } 4 \\
\text { months later }\end{array}$ \\
\hline $11(59 / \mathrm{M})$ & $\begin{array}{l}\text { Coronary } \\
\text { artery bypass }\end{array}$ & $\cdots$ & $\begin{array}{l}\text { Mild amnesia, acalculia, spatial } \\
\text { disorientation }\end{array}$ & $\begin{array}{l}\text { Improved to } 20 / 40 \text { OU and CF } \\
\text { in superior fields } 2 \text { years later }\end{array}$ \\
\hline $12(63 / \mathrm{M})$ & $\begin{array}{l}\text { Coronary } \\
\text { artery bypass }\end{array}$ & $\mathrm{RHH}$ & Disorientation, left hemiparesis & $\begin{array}{l}\text { Improved to } 20 / 30 \text { OU and } C F \\
\text { in left VF } 6 \text { months later }\end{array}$ \\
\hline $13(30 / F)$ & $\begin{array}{l}\text { Aortic valve } \\
\text { replacement }\end{array}$ & $\cdots$ & Left arm ataxia & $\begin{array}{l}\text { Improved to } 20 / 40 \text { OU and near } \\
\text { normal VF } 4 \text { months later }\end{array}$ \\
\hline $14(63 / M)$ & Laryngeal surgery & $\cdots$ & $\begin{array}{l}\text { Left hemiparesis, left sensory } \\
\text { neglect }\end{array}$ & $\begin{array}{l}\text { No improvement; died } 2 \text { months } \\
\text { later }\end{array}$ \\
\hline $15(54 / F)$ & $\begin{array}{l}\text { Craniotomy for } \\
\text { meningioma }\end{array}$ & $\mathrm{RHH}$ & $\begin{array}{l}\text { Right sensory neglect, right } \\
\text { hemiparesis }\end{array}$ & $\begin{array}{l}\text { Improved to prior RHH } 4 \\
\text { months later }\end{array}$ \\
\hline $16(37 / \mathrm{M})$ & $\begin{array}{l}\text { Craniotomy for } \\
\text { meningioma }\end{array}$ & $\cdots$ & None & $\begin{array}{l}\text { Improved to normal } 2 \text { months } \\
\text { later }\end{array}$ \\
\hline $17(54 / \mathrm{F})$ & $\begin{array}{l}\text { Craniotomy for } \\
\text { occipital heman- } \\
\text { giopericytoma }\end{array}$ & $\cdots$ & $\begin{array}{l}\text { Coma; later left hemiparesis, } \\
\text { aphasia, left sensory loss }\end{array}$ & No improvement 3 years later \\
\hline $18(35 / \mathrm{M})$ & $\begin{array}{l}\text { Cerebral } \\
\text { angiography }\end{array}$ & $\cdots$ & Left hemiparesis, dysarthria & $\begin{array}{l}\text { Improved to normal } 1 \text { month } \\
\text { later }\end{array}$ \\
\hline $19(26 / \mathrm{M})$ & Cardiac arrest & $\ldots$ & $\begin{array}{l}\text { Spastic dysarthria, spastic } \\
\text { quadriparesis }\end{array}$ & No improvement 1 year later \\
\hline $20(65 / M)$ & $\begin{array}{l}\text { Cerebral } \\
\text { angiography }\end{array}$ & $\cdots$ & Disorientation, mild amnesia & $\begin{array}{l}\text { Slight improvement } 6 \text { months } \\
\text { later }\end{array}$ \\
\hline $21(64 / M)$ & $\begin{array}{l}\text { Cerebral } \\
\text { angiography }\end{array}$ & $\cdots$ & $\begin{array}{l}\text { Disorientation, vertical } \\
\text { nystagmus, left hemiparesis }\end{array}$ & $\begin{array}{l}\text { Improved to } 20 / 25 \text { OU with } \\
\text { right inferior quadrantanopia }\end{array}$ \\
\hline $22(24 / \mathrm{M})$ & Head trauma & $\cdots$ & None & Improved to normal 1 week later \\
\hline $23(33 / \mathrm{M})$ & Partial seizures & $\cdots$ & Left sensory extinction & $\begin{array}{l}\text { Improved to RHH } 8 \text { months } \\
\text { later }\end{array}$ \\
\hline $24(57 / M)$ & Peritoneal dialysis & $\cdots$ & Amnesia, left facial weakness & $\begin{array}{l}\text { Regained only macular vision } 6 \\
\text { months later }\end{array}$ \\
\hline $25(63 / \mathrm{M})$ & Azotemia seizures & $\cdots$ & Disorientation, perseveration & $\begin{array}{l}\text { Improved to condition of prior } \\
\text { vision } 3 \text { days later }\end{array}$ \\
\hline
\end{tabular}

$\mathrm{VF}=$ visual field; $\mathrm{RHH}=$ right homonymous hemianopia; $\mathrm{LHH}=$ left homonymous hemianopia; $\mathrm{OU}=$ both eyes; $\mathrm{CF}=$ count fingers. 


\begin{tabular}{|c|c|c|c|c|}
\hline \multirow[b]{2}{*}{ Patient Data } & \multicolumn{3}{|c|}{ Cause } & \multirow[b]{2}{*}{ Total } \\
\hline & Stroke ${ }^{a}$ & Operation & Other ${ }^{b}$ & \\
\hline No. of patients & 8 & 9 & 8 & 25 \\
\hline Average age (yr) & 64 & 54 & 46 & 51 \\
\hline Sex: $M / F$ & $6 / 2$ & $5 / 4$ & $8 / 0$ & $19 / 6$ \\
\hline Hypertension & 6 & 4 & 3 & 13 \\
\hline Use of tobacco & 7 & 5 & 4 & 16 \\
\hline Diabetes mellitus & 2 & $\ldots$ & 4 & 6 \\
\hline \multicolumn{5}{|l|}{ Associated neurological deficits } \\
\hline None & 1 & 1 & 1 & 3 \\
\hline Disorientation only & 1 & 1 & 1 & 3 \\
\hline Cognitive/language/memory & 6 & 3 & 2 & 11 \\
\hline Sensory/motor & 4 & 5 & 3 & 12 \\
\hline Brainstem/cerebellar & $\ldots$ & 2 & 2 & 4 \\
\hline Absent OKN & $4 / 6$ & $5 / 5$ & $8 / 8$ & $17 / 19$ \\
\hline \multicolumn{5}{|l|}{ Vision-peripheral } \\
\hline No light perception & 2 & 4 & 3 & 9 \\
\hline Light perception only & 3 & 1 & 3 & 7 \\
\hline Light and motion only & 2 & 2 & 1 & 5 \\
\hline $\begin{array}{l}\text { Count fingers in at least } \\
\text { one hemifield }\end{array}$ & 1 & 2 & 1 & 4 \\
\hline \multicolumn{5}{|l|}{ Vision-central } \\
\hline Macular sparing & 1 & 4 & 0 & 5 \\
\hline Hallucinations & 1 & 3 & 2 & 6 \\
\hline Denial or unawareness & 2 & 5 & $\ldots$ & 7 \\
\hline
\end{tabular}

${ }^{\text {aN }}$ ot related to surgery or inhospital procedures.

${ }^{b}$ Cortical blindness associated with angiography (3), cardiac arrest (1), peritoneal dialysis (1), head trauma (1), partial seizures (1), azotemia with seizures (1).

$\mathrm{OKN}=$ optokinetic nystagmus.

mittent low-amplitude alpha activity that was unresponsive to eye opening. Epileptiform activity was present in 3 patients. A $7-\mathrm{Hz}$ posterior rhythm attenuated with eye opening in 1 patient (No 6) and photic stimulation induced a posterior evoked response in 3 patients (Nos 4, 18, and 20).

PRVEPs recorded during blindness were abnormal in 7 of 9 patients. In 1 man with complete cortical blindness (Patient 1), PRVEPs showed clearly identifiable P100 waves with normal latency. FVEPs were abnormal in 8 of 10 patients, but only 1 patient showed no response (No 18).

In several patients, diagnosis was initially inaccurate or delayed, and a correct diagnosis was not made until the patient was referred for neurological or ophthalmological evaluation. Macular sparing, preexisting abnormal pupillary responses, and failure to complain of visual loss contributed to the diagnostic difficulty. Psychogenic visual loss was an initial consideration in 2 patients with exaggerated and variable responses to visual loss and in 1 patient with blindness as the sole symptom.

\section{Prognosis}

The extent of recovery of vision is shown in Table 4. Significantly better outcomes were seen in patients under the age of 40 years $(p<0.01)$, in those without a history of diabetes or hypertension $(p<0.05)$, and in those without associated cognitive, language, or memory impairment $(p<0.01)$. Prognosis also varied depending on the cause of blindness. All 8 patients with $\mathrm{CB}$ following spontaneous stroke made poor or no recovery while $65 \%$ of the others had a fair or good outcome $(p<0.05)$.

None of the 14 patients with bioccipital CT abnormalities had good recovery of vision, but 3 of the 5 patients with normal or unilaterally abnormal CT scans made good recoveries $(p<0.05)$. Optokinetic responses were present in 2 patients (Nos 5 and 7), but neither had good outcomes.

EEG abnormalities (see Table 3) were present in all patients who were tested. The presence of lowamplitude alpha frequency activity in 5 patients was not associated with a good outcome in any patient. Specific VEP abnormalities included abnormalities of 


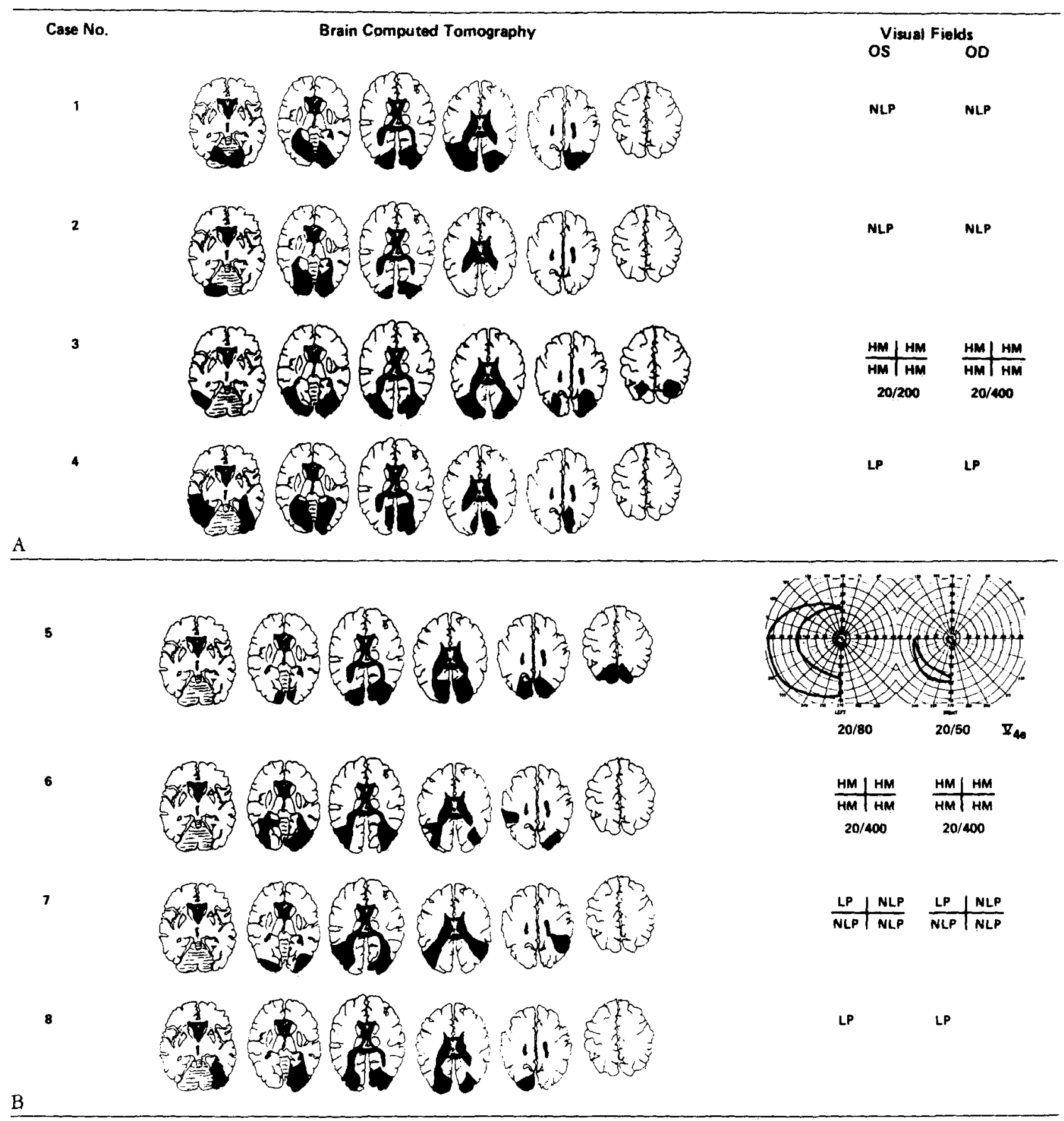

Fig 1. Brain computed tomograpbic findings and visual fields in 8 patients with cortical blindness due to spontaneous stroke. (OS $=$ left eye $: \mathrm{OD}=$ right eye $; \mathrm{OU}=$ both eyes; $\mathrm{NLP}=$ no light perception; $\mathrm{LP}=$ light perception only; $\mathrm{HM}=$ light and hand motion perception only.) 


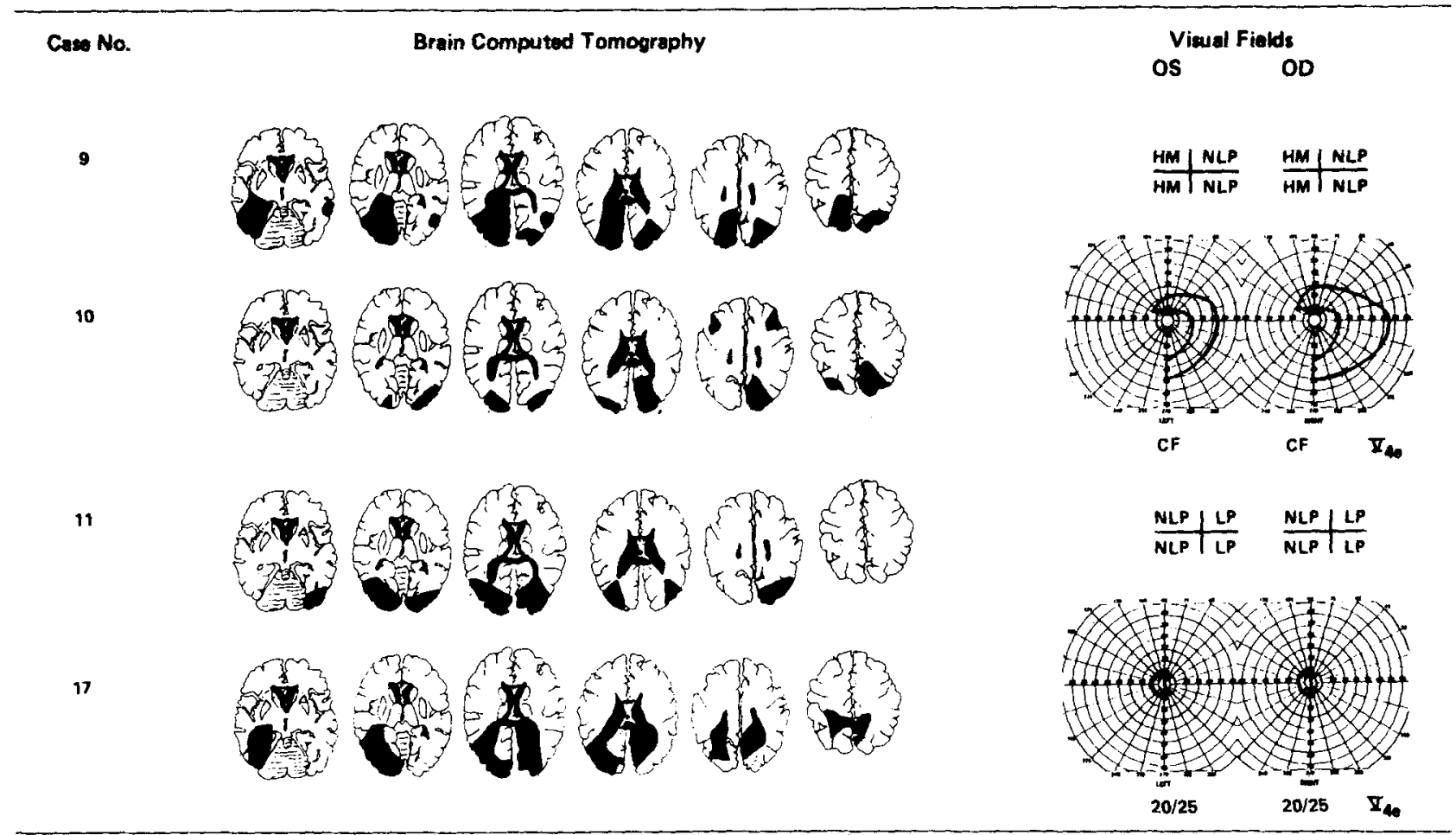

Fig 2. Brain computed tomographic findings and visual fields in 4 patients with cortical blindness associated with surgery. (Abbreviations same as in Figure 1.)

Cmo No.

Fig 3. Brain computed tomographic findings and visual fields in 4 patients with cortical blindness due to cerebral angiography, cardiac arrest, seizures, and peritoneal dialysis. (Abbreviations same as in Figure 1.) 


\begin{tabular}{|c|c|c|c|c|}
\hline \multirow[b]{2}{*}{ EEG and VEP Results } & \multicolumn{3}{|c|}{ Outcome } & \multirow[b]{2}{*}{ Total } \\
\hline & Poor & Fair & Good & \\
\hline FVEP (No. of patients) & 7 & 0 & 3 & 10 \\
\hline Normal & 2 & $\ldots$ & . & 2 \\
\hline Unilaterally prolonged latency & 1 & $\cdots$ & 1 & 2 \\
\hline Bilaterally prolonged latencies & 2 & $\ldots$ & $\ldots$ & 2 \\
\hline Unilaterally low amplitude & $\ldots$ & $\ldots$ & 1 & 1 \\
\hline Bilaterally low amplitude & 2 & $\ldots$ & $\cdots$ & 2 \\
\hline No response & $\ldots$ & $\cdots$ & 1 & 1 \\
\hline PRVEP (No. of patients) & 7 & 1 & 1 & 9 \\
\hline Normal & 2 & $\ldots$ & $\ldots$ & 2 \\
\hline Bilaterally prolonged latencies & 2 & $\ldots$ & $\ldots$ & 2 \\
\hline No response & 3 & 1 & 1 & 5 \\
\hline EEG (No. of patients) & 14 & 3 & 3 & 20 \\
\hline Abnormal & 14 & 3 & 3 & 20 \\
\hline \multicolumn{5}{|l|}{ Reactivity } \\
\hline To eye opening & 1 & $\ldots$ & $\cdots$ & 1 \\
\hline To photic stimulation & 2 & $\ldots$ & 1 & 3 \\
\hline Alpha rhythm present & $\ldots$ & $\ldots$ & $\ldots$ & 0 \\
\hline Alpha frequency activity present & 5 & $\ldots$ & $\cdots$ & 5 \\
\hline
\end{tabular}

EEG $=$ electroencephalogram; FVEP $=$ flash visual evoked potentials; PRVEP $=$ pattern reversal visual evoked potentials.

latency, amplitude, or both, or no response. All patients with normal FVEPs (Nos 14 and 19) and normal PRVEPs (Nos 1 and 20) during blindness had poor outcomes. Three patients with good outcomes (Nos 13,18 , and 25) had abnormal FVEPs during blindness. One man (Patient 18) with a good outcome had PRVEPs during blindness, which showed no response.

\section{Discussion}

Although stroke remains the most common cause of $\mathrm{CB}$, surgery, especially cardiac surgery, and cerebral angiography are now frequent causes. Cardiac surgery, which was rarely performed three decades ago, may cause cerebral dysfunction through a variety of mechanisms, including anoxia from hypoperfusion [10, 17, 46], cerebral hemorrhage [2, 17], and blood, fat, and air embolism [10, 17]. Ischemic neuronal damage of the calcarine cortex is frequent in patients who do not survive heart surgery $[2,40,41]$.

Mechanisms that have been postulated to explain $\mathrm{CB}$ following angiography include distuption of the blood-brain barrier $[24,26]$, concurrent hypotension [47], embolism [16], and vasospasm [34, 48]. The incidence of $\mathrm{CB}$ in one study was $0.8 \%$ of all vertebral angiographic procedures [25]. Two of the three patients with $\mathrm{CB}$ following angiography in our series suffered permanent visual deficits, in contrast to previous studies that emphasized the favorable prognosis of $\mathrm{CB}$ in almost all cases due to angiography $[24,25,39]$.
Our study does not support the contention that nonoperative cardiac arrest is a frequent cause of $C B$ [15]. The low incidence of trauma in our series may reflect the patient population in our hospitals; none of our patients suffered war injuries, which have caused most reported cases of traumatically induced CB [23, $36,42]$. Trauma may, however, be a more frequent cause in children $[18,20]$.

Denial of blindness is rare, and in our series occurred only in patients with complete blindness and severe memory impairment, providing support for the hypothesis that denial may sometimes result from the inability of the patient to remember his or her own blindness [31]. In our Patient 14, denial appeared at the same time as the loss of the slight remaining vision, suggesting that in some cases completeness of visual loss may facilitate the denial of blindness. Although unawareness or inattention to visual loss also occurs, most of our patients appeared fully aware of their visual loss.

In patients with $C B$, careful examination will usually demonstrate preservation of some visual function. Residual vision in the form of light or motion perception was common in our patients; less than $10 \%$ of our patients had permanent complete cortical blindness, which is consistent with previous reports that incomplete blindness is more common than complete [11].

For the clinician unfamiliar with $\mathrm{CB}$, diagnosis of incomplete cortical blindness may be difficult. Op- 


\begin{tabular}{|c|c|c|c|c|}
\hline \multirow[b]{2}{*}{ Patient Data } & \multicolumn{3}{|c|}{ Outcome $^{a}$} & \multirow[b]{2}{*}{ Total } \\
\hline & Poor & Fair & Good & \\
\hline No. of patients & 14 & 5 & 6 & 25 \\
\hline \multicolumn{5}{|l|}{ Cause } \\
\hline Spontaneous stroke $e^{b}$ & 8 & $\ldots$ & $\cdots$ & 8 \\
\hline Surgery & 3 & 3 & 3 & 9 \\
\hline Other & 3 & 2 & 3 & 8 \\
\hline Age: $>40 /<40^{c}$ & $13 / 1$ & $3 / 2$ & $2 / 4$ & $18 / 7$ \\
\hline Sex: $M / F$ & $10 / 4$ & $5 / 0$ & $4 / 2$ & $19 / 6$ \\
\hline Hypertension (HTN) & 9 & 3 & 1 & 13 \\
\hline Diabetes mellitus (DM) & 5 & 1 & 0 & 6 \\
\hline Neither DM nor HTN ${ }^{c}$ & 2 & 2 & 5 & 9 \\
\hline \multicolumn{5}{|l|}{ Neurological deficits } \\
\hline None or disorientation only & 2 & 1 & 3 & 6 \\
\hline Cognitive/language/memory ${ }^{\mathrm{b}}$ & 10 & 1 & $\ldots$ & 11 \\
\hline Sensory/motor & 7 & 3 & 2 & 12 \\
\hline Brainstem/cerebellar & 1 & 1 & 2 & 4 \\
\hline \multicolumn{5}{|l|}{ Vision } \\
\hline No light perception & 4 & 1 & 4 & 9 \\
\hline Light perception only & 5 & 1 & 1 & 7 \\
\hline Light and motion only & 3 & 1 & 1 & 5 \\
\hline Count fingers: at least one hemifield & 2 & 2 & $\ldots$ & 4 \\
\hline Macular sparing & 2 & 1 & 2 & 5 \\
\hline \multicolumn{5}{|l|}{ Computed tomography } \\
\hline Normal & 1 & $\cdots$ & 2 & 3 \\
\hline Unioccipital abnormality & & 1 & 1 & 2 \\
\hline Bioccipital abnormality ${ }^{c}$ & 12 & 2 & $\ldots$ & 14 \\
\hline
\end{tabular}

${ }^{2}$ The outcome for each condition was compared to the outcome for patients without that condition using the Wilcoxon rank order method. ${ }^{\mathrm{b}} p<0.01$.

$c_{p}<0.05$.

tokinetic responses were preserved in 2 of our patients with incomplete blindness, indicating that this test cannot always be used to distinguish CB from psychogenic blindness $[11,29,38]$. In our study, five factors appeared to contribute to diagnostic uncertainty for the referring physician: (1) preexisting pupillary abnormalities or prechiasmal lesions; (2) macular sparing, which was mistaken for hysterical tubular visual fields; (3) variation of visual perception over time, especially when associated with cognitive or language deficits; (4) complaints of blindness that were out of proportion to objectively measured visual field loss; and (5) occurrence of $\mathrm{CB}$ without other neurological abnormalities or only in association with disorientation. In most of these patients, the diagnosis was apparent following complete neuroophthalmological assessment; however, in patients with cognitive and language impairments and in critically ill patients, a full neuroophthalmological evaluation may not be possible. CT was useful in documenting objective evidence of occipital dysfunction, either when psychogenic visual loss was suspected or when preexisting pupillary abnormalities raised the possibility of prechiasmal lesions.

The EEG, with assessment of reactivity to eye opening and photic stimulation, is a sensitive indicator of geniculocalcarine dysfunction. Reported EEG findings in patients with $\mathrm{CB}$ include reduced voltage over occipital areas [49] and no alpha rhythm [5, 37, 49]. Since the absence of an alpha rhythm is not abnormal, its absence cannot be taken as diagnostic of CB. The alpha rhythm, a posterior dominant visually responsive rhythm, can be distinguished from alpha frequency activity, which refers to any activity in the $8-$ to $13-\mathrm{Hz}$ range. Alpha frequency activity has been noted in the EEGs of occasional patients with $C B[7,8,27]$, but has not been reported to be responsive to eye opening. In 4 of our patients, EEGs showed occasional low-voltage unresponsive alpha activity. A posterior dominant alpha rhythm that is responsive to eye opening appears to be incompatible with complete or incomplete $\mathrm{CB}$.

The role of PRVEPs and FVEPs in evaluating CB is controversial. A variety of abnormalities have been re- 
ported $[1,4,12-14,22,27,33,43]$. However, FVEPs may be normal in complete $\mathrm{CB}[8,12]$ and in incomplete $\mathrm{CB}$ [22], and our finding of a normal $\mathrm{p} 100$ wave in Patient 1 is consistent with the observation of Celesia and associates [12] that normal PRVEPs can occur with $\mathrm{CB}$.

Abnormal PRVEPs are not helpful in excluding psychogenic blindness, as poor fixation can induce abnormalities. Abnormal FVEPs may be helpful in this regard; however, the variable abnormalities of latency and amplitude may make it impossible to distinguish retrochiasmal from chiasmal and prechiasmal lesions. Topographic variability of the visual cortex and the large corrical representation of the macula may explain the variation of VEP abnormalities [13], but until the appropriate stimulus and response parameters have been determined, VEPs will have limited diagnostic utility for the evaluation of $\mathrm{CB}[6,7,28]$.

$\mathrm{CB}$ may occur as part of a transient ischemic attack, but our results indicate that reliable statements concerning prognosis can be made 24 to 48 hours after the onset of blindness in parients with CB resulting from vascular disease. When spontaneous stroke was the cause, the outcome was poor in all cases. In contrast to the study of Horwitz and Wener [24], CB in association with angiography was not always a transient disorder in our series. In cases of $\mathrm{CB}$ due to nonvascular or nonsurgical causes, the prognosis is generally good, and substantial improvement can be expected, particularly in younger patients.

In our series, no patient with bioccipital CT abnormalities from any cause had good recovery of vision. Hence, CT, performed at least 1 week after the onset of blindness, provides useful prognostic information in patients with CB. Complete visual loss with no light perception is uncommon, but when present it is a poor prognostic sign.

We did not find EEGs or VEPs helpful prognostically. Preservation of some alpha frequency activity or some response to photic stimulation did not help to predict outcome in our study. Absent FVEPs are reported to indicate a poor prognosis [1], but the complete absence of a flash evoked response occurred in 1 of our patients who went on to a full recovery. We observed normal PRVEPs in 2 patients with a poor outcome and normal FVEPs in 2 others with a poor outcome, consistent with previous studies showing that FVEPs may be preserved in patients with poor outcomes [12]. The utility of VEPs for prognostic purposes therefore remains questionable.

Presented in part at the 109 th Annual Meeting of the American Neurological Association, Baltimore, MD, October 1984.

\section{References}

1. Abraham FA, Melamed E, Lavy S: Prognostic value of visual evoked potentials in occipital blindness following basilar artery occlusion. Appl Neurophysiol 38:126-135, 1975

2. Aguilar MJ, Gerbode F, Hill JD: Neuropathologic complications of cardiac surgery. J Thorac Cardiovasc Surg 61:676-685, 1971

3. Aldrich MS, Vanderzant C, Abou-Khalii B, et al: Cortical Blindness as an ictal manifestation. Electroencephalogr Clin Neurophysiol 61:37P, 1985

4. Barnet $\mathrm{AB}$, Manson JI, Wilner $\mathrm{E}$ : Acure cerebral blindness in childhood: six cases studied clinically and electrophysiologically. Neurology 20:1147-1156, 1970

5. Bergman PS: Cerebral blindness: an analysis of twelve cases, with especial reference to the electroencephalogram and patterns of recovery. Arch Neurol Psychiatry 78:568-584, 1957

6. Blumhardt LD, Halliday AM: Hemispheric contributions to the composition of the pattern-evoked potential waveform. Exp Brain Res 36:53-69, 1979

7. Bodis-Wollner I: Recovery from cerebral blindness: evoked potential and psychophysical measurements. Electroencephalogr Clin Neurophysiol 42:178-184, 1977

8. Bodis-Wollner I, Atkin A, Raab E, Wolkstein M: Visual association cortex and vision in man: pattern-evoked occipital potentials in a blind boy. Science 198:629-631, 1977

9. Bogousslavsky J, Regli F, Van Melle G: Unilateral occipital infarction: evaluation of the risks of developing bilateral loss of vision. J Neurol Neurosurg Psychiatry 46:78-80, 1983

10. Brierly JB: Neuropathological findings in patients dying after open-heart surgery. Thorax 18:291-304, 1963

11. Brindley GS, Gautier-Smith PC, Lewin W: Cortical blindness and the functions of the non-geniculate fibres of the optic tracts. J Neurol Neurosurg Psychiatry 32:259-264, 1969

12. Celesia GG, Archer CR, Kuroiwa Y, Goldfader PR: Visual function of the extrageniculo-calcarine system in man: relationship to cortical blindness. Arch Neurol 37:704-706, 1980

13. Celesia GG: Evoked potential techniques in the evaluation of visual function. J Clin Neurophysiol 1:55-76, 1984

14. Chisholm IH: Cortical blindness in cranial arteritis. $\mathrm{Br} J$ Ophthalmol 59:332-333, 1975

15. Drymalski WG: Cortical blindness: the changing incidence and shifting etiology. Postgrad Med J 67:149-156, 1980

16. Falls HF, Bassett RC, Lamberts AE: Ocular complications encountered in intracranial arteriography. Atch Ophthalmol 45:623-626, 1951

17. Gilman S: Cerebral disorders after open-heart operations. N Engl J Med 272:489-498, 1965

18. Gjerris F, Mellemgaard L: Transitory cortical blindness in head injury. Acta Neurol Scand 45:623-631, 1969

19. Gloning I, Gloning K, Tschabitscher H: Die occipitale Blindheit auf vascularer Basis. Albrecht Von Graefes Archiv Ophthalmol $165: 138-177,1962$

20. Griffith JF, Dodge PR: Transient blindness following head injury in children. N Engl J Med 278:648-651, 1968

21. Hayman LA, Berman SA, Hinck VC: Correlation of CT cerebral vascular territories with function: II. Posterior cerebral artery. Am J Roentgenol 137:13-19, 1981

22. Hess CW, Meienberg O, Ludin HP: Visual evoked porentials in acute occipital blindness: diagnostic and prognostic value. J Neurol 227:193-200, 1982

23. Holmes G: Disturbances of vision by cerebral lesions. Br J Ophthalmol 2:353-384, 1918

24. Horwitz NH, Wener L: Temporary cortical blindness following angiography. J Neurosurg 40:583-586, 1974

25. Jorgensen J, Sigurdsson J, Ovesen N: Complications of verte- 
bral angiography by the Seldinger technique: a survey of 619 cases. Dan Med Bull 17:132-135, 1970

26. Kaplan AD, Walker AE: Complications of cerebral angiography. Neurology 4:643-656, 1954

27. Kooi KA, Sharbrough FW: Electrophysiological findings in cortical blindness: report of a case. Electroencephalogr Clin Neurophysiol 20:260-263, 1966

28. Kuroiwa Y, Celesia GG: Visual evoked potentials with hemifield pattern stimulation: their use in the diagnosis of retrochiasmatic lesions. Arch Neurol 38:86-90, 1981

29. Magitot A, Hartmann E: La cecite corticale. Rev D'Oto-neurooculistique $5: 81-114,1927$

30. Matsui T, Hirano A: An Atlas of the Human Brain for Computerized Tomography. New York, Igaku-Shoin, 1978,pp 13-81

31. Miller N: Walsh and Hoyt's Clinical Neuro-ophthalmology. Baltimore, Williams \& Wilkins, 1982, p 144

32. Nepple EW, Appen RE, Sackett JF: Bilateral homonymous hemianopsia. Am J Ophthalmol 86:536-543, 1978

33. Perenin MT, Ruel J, Hecaen H: Residual visual capacities in a case of cortical blindness. Cortex 16:605-612, 1980

34. Prendes JL: Transient cortical blindness following vertebral angiography. Headache 18:222-224, 1978

35. Reese FM: Bilateral homonymous hemianopsia. Am J Ophthalmol 38:44-57, 1954

36. Riddoch G: Dissociation of visual perceptions due to occipital injuries, with especial reference to appreciation of movement. Brain 40:15-57, 1917

37. Rossen R, Jeub RP: Cortical blindness after cardiac arrest, report of two cases with recovery. Clin Electroencephalogr $1: 165-170,1970$
38. Sadeh M, Goldhammer Y, Kuritsky A: Postictal blindness in adults. J Neurol Neurosurg Psychiatry 46:566-569, 1983

39. Silverman SM, Bergman PS, Bender MB: The dynamics of transient cerebral blindness: report of nine episodes following vertebral angiography. Arch Neurol 4:333-348, 1961

40. Silverstein A, Krieger HP: Neurologic complications of cardiac surgery. Arch Neurol 3:601-605, 1960

41. Smith JL, Cross SA: Occipital lobe infarction after open heart surgery. J Clin Neuro-ophthalmol 3:23-30, 1983

42. Spalding JMK: Wounds of the visual pathway. Part II: The striate cortex. J Neurol Neurosurg Psychiatry 15:169-183, 1952

43. Spehlmann R, Gross RA, Ho SU, et al: Visual evoked potentials and postmortem findings in a case of cortical blindness. Ann Neurol 2:531-534, 1977

44. Symonds C, Mackenzie I: Bilateral loss of vision from cerebral infarction. Brain 80:415-455, 1957

45. Ter Braak JWG, Schenk VWD, Van Vliet AGM: Visual reactions in a case of long-lasting cortical blindness. J Neurol Neurosurg Psychiatry 34:140-147, 1971

46. Tufo HM, Ostfeld AM, Shekelie R: Central nervous system dysfunction following open-heart surgery. JAMA 212:13331340,1970

47. Walsh FB, Hoyt WF: Clinical Neuro-ophthalmology, ed 3. Baltimore, Williams \& Wilkins, 1969, p 2508

48. Weatherall M: The pharmacological actions of some contrast media and a comparison of their merits. Br J Radiol 15:129137,1942

49. Williams D, Reynell J: Abnormal suppression of cortical frequencies. Brain 68:123-161, 1945 